\title{
An Investigation into the Influence of a Temperature Load of a Suspended Roof in Measurements for Diagnostic Purposes
}

\section{Loads over Suspended Roofs and Their Consequences}

It is snow and ice load, temperature, wind and dead loads or pretensioning which are named in the literature $[13,14]$ as those having a significant impact on work of roofs, but first of all, on the safety of operations and the use of a structure. The main problem in suspended roofs - open structures - is the presence of many (actually most) of these loads at the same time. They cause, in a practically continuous way, changing forces acting on a structure and thereby changing the geometry of the structure. longterm tensile load causes the gradual lengthening and thereby causes a decrease in the tension forces adversely changing conditions of stability of the construction work [10].

The main load is the snow and ice load. It creates a real threat to the safety of the structure, especially in the case of roofs of large span between supports [6, 7]. A specific type of load are changes of temperature. The impact of these changes is particularly important in the case of pretensioned constructions, because they can lead to a significant growth (decline) in cables [13, 14]. Disregarding the impact of the temperature load can also lead to a degradation of the structure [11], a failure or a disaster. The proper assessment of the current load (especially in the case of an abnormal snowfall [17] and/ or temperature changes) is always essential when assessing the safety of the facility. At the stage of the operation the assessment can be performed using the results of the survey, to which and on which [16] appropriate corrections should always be placed.

\section{The Impact of Temperature and Temperatures of a Construction}

Thermal, climatic actions on construction elements are treated as changing influences which are caused by changes of temperature fields at a specified period of time. In order to determine the thermal effects one should use coefficients of a linear

* Koszalin University of Technology, Faculty of Civil Engineering, Environmental and Geodetic Sciences, Department of Geodesy, Koszalin, Poland 
expansion [15]. According to the standard [15] the factor $12 \cdot 10^{-6}\left[1 /{ }^{\circ} \mathrm{C}\right]$ should be adopted for steel structures.

While designing which includes a static analysis of a structure there are always some characteristic temperatures (or differences of temperatures), for which strength calculations should be carried out, taken. They should also be taken into account when preparing an expert opinion of the safety of a facility in different conditions. If the initial temperature when structural elements are consolidated is not known, the initial temperature $T_{0}=8^{\circ} \mathrm{C}$ is assumed [15]. The values of the maximum shade air temperature $\left(\mathrm{T}_{\max }\right)$ for summer time and minimum $\left(T_{\min }\right)$ for the winter season necessary to assess the outside temperature of an element are determined from national maps of isotherms of a EU country, which are prepared using the statistical analysis (annual probability of being exceeded of 0.02 - equivalent to a mean return period of 50 years) $[12,15]$. On the basis of these isotherms $T_{\max }$ read from the map should be reduced to the maximum temperature $T_{\max }(H)$ referred to the level $(H)$ of the location of the object expressed in meters above the sea level: $T_{\max }(H)=-0.0053\left({ }^{\circ} \mathrm{C} / \mathrm{m}\right) H+T_{\max }$. The minimum temperature is determined similarly, and then: $T_{\min }(H)=-0,0035\left({ }^{\circ} \mathrm{C} / \mathrm{m}\right) H+T_{\min }$. For a given construction the outdoor temperature $\left(T_{\text {out }}\right)$ based on the specific $T_{\text {max }}$ and $T_{\min }$ is also defined, thereby taking the impact of solar radiation effects into consideration by adding an appropriate component. In summer it is determined on the relative absorption coefficient of heat at the external surface of the structure (depending on the colour of the surface) and its orientation (the effect of insolation depending on the sun exposure). In winter, the predetermined $T_{\min }$ is assumed to be the $T_{\text {out }}$.

\section{The Suspended Roof over the Open-air Theatre in Koszalin}

The roof over the open-air theatre in Koszalin (Fig. 1) is an open suspended roof protecting the entire gallery and the stage from precipitation. It was designed and built in 1975. The roof projection is lens shaped and consists of two circular sectors. The shape of the surface resembles a hyperbolic paraboloid.

The base of the supporting construction is made of two elliptic, flat, steel, double hinged arches. The arches are arranged in planes inclined at about $30^{\circ}$. Their work in oblique planes is determined by three pairs of guys on either side. Suspension members (cables) span between the arches support tension members (I sections). Trapezium sectioned galvanized and coated steel sheet is fastened to the I section by means of Hilti pins [5]. The supporting arches rest with their ends, by spherical hinges, against reinforced concrete abutments, each being 
monolithically connected to a reinforced concrete slab resting on 44 Franki piles. The main parameters of the object are projected roof surface $4460 \mathrm{~m}^{2}$, roof span $101.8 \mathrm{~m}$ and $56.8 \mathrm{~m}[5]$.

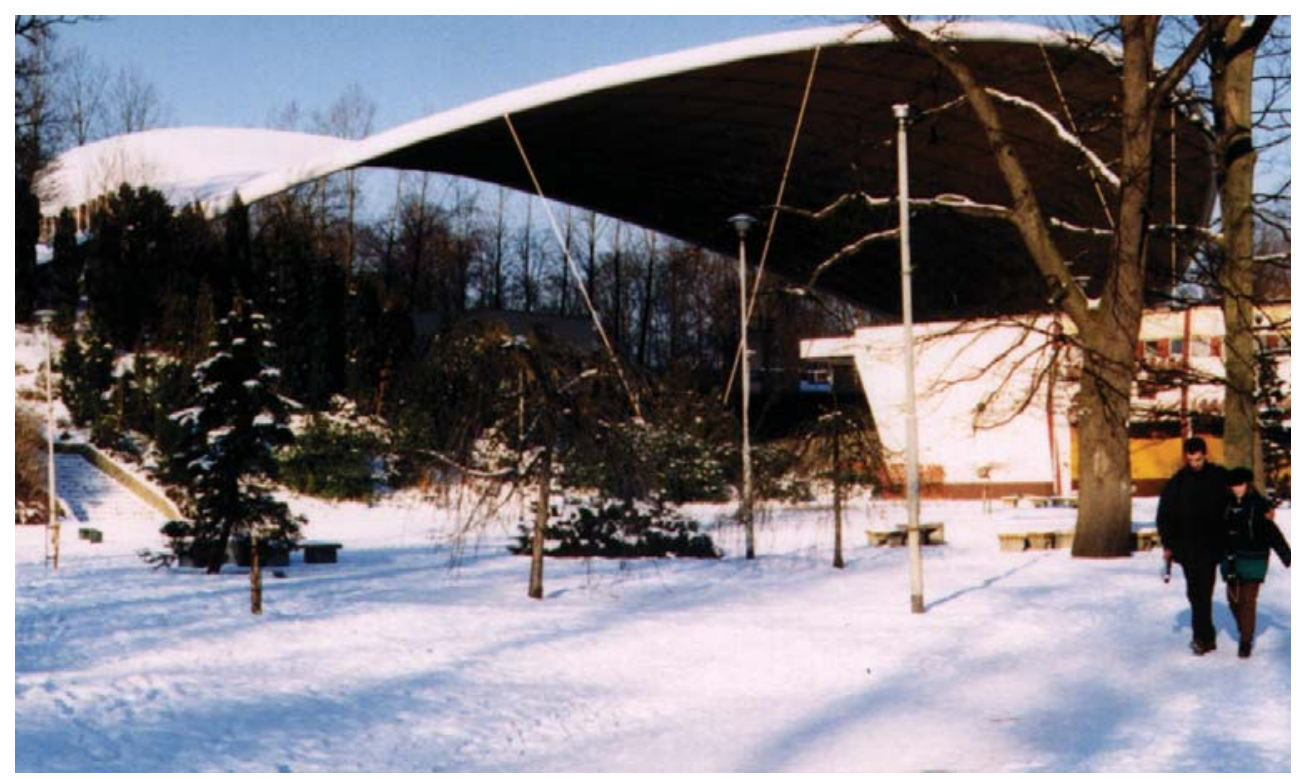

Fig. 1. The suspended roof over open-air theatre in Koszalin

Source: materials of the constructor of the roof

\section{Measurements Performed for Diagnostic Purposes and Static Analyses}

Methodology of the registration of the geometrical structure of roofs for the diagnostics purposes has been the subject of detailed studies [1] whose results were also presented in $[3,4]$. On their basis it was stated that in the case of the registration of several selected points in each measurement period the method of polar coordinates with free stations is the most effective. When having appropriate conditions of observations (stable temperature, cloud covering which limits the varied sun exposure and no wind) the accuracy of determined position of controlled (signalled) points of structures of suspended roofs at the level of $1 \mathrm{~cm}$ can be obtained. The method of polar coordinates is used to register the position of selected nodes of a construction in periodic measurements with snow and ice loads - to determine their displacements. For this purpose specially designed targets [1, 2] were installed in selected by the constructor grid nodes (Fig. 2). 


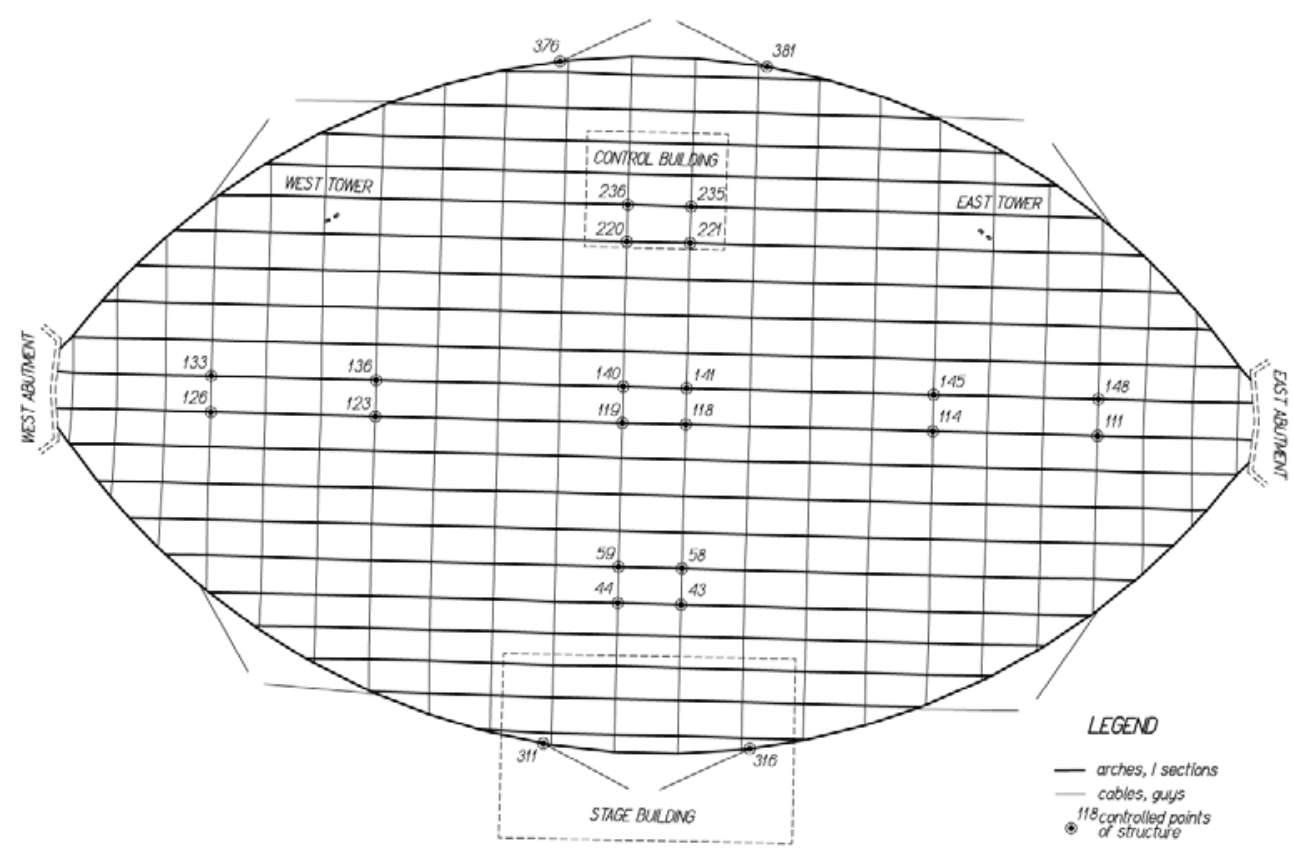

Fig. 2. Projection of the construction grid and position of controlled points

Based on calculations made by ROBOT Millennium [1, 6-8], variations of work of the construction at various values of distribution of snow and ice loads were analyzed. The results of surveys carried out in 2006-2012, mainly during winter when snow and ice covered the roof (and associated with the measurements of the thickness of the cover and the weight of the selected points) confirmed the correctness of the performed calculations.

The expert opinion prepared for the designed study [6] states that the maximum displacement due to the snow and ice load should not exceed $-70 \mathrm{~cm}$ in the central part (points: 118, 119, 141, 140) (Fig. 2). Therefore for a few years (especially in winter) measurements and calculations have been carried out periodically. Methodology of deflection calculations - vertical displacement of the node of the grid of the construction which have been used so far involves using as a reference a state of a construction with no additional snow and ice load at a temperature as close as possible to the present one. But it is hard to imagine that in the case of long-lasting, negative temperatures and residual snow and ice, measurement results can be compared and displacements calculated without having the comparative data the displacement of comparative data (no snow and ice load) for very low temperatures. The observed changes in the vertical position of the above points, at differences of temperatures of $39^{\circ} \mathrm{C}$ which resulted in changes in temperature only reached up $20 \mathrm{~cm}$. 
This fully justifies the need to take into account the temperature load when calculating the acceptable and current value of displacements.

\section{Attempts to Reflect the Impact of a Temperature Load on a Construction}

Temperatures characteristic - calculated (shade air temperatures) [15] specified for the location and conditions of the tested object in accordance with the principles set out in chapter 2 - are as follows: $T_{\max }(H)=38^{\circ} \mathrm{C}, T_{\min }(H)=T_{\text {out }}=-27^{\circ} \mathrm{C}$.

Considering only individual elements of a structure, a linear relationship between a temperature and a sag (or elevation) of the midpoint of a suspension or a tension member can be made. Two central tension members (I sections) projected onto a vertical plane are approximately parabolic arches with a constant crosssection, without hinges - established in reinforced concrete abutments. Each of the arches - the first one containing points: 111, 114, 118, 119, 123, 126 and second one containing: 133, 136, 140, 141, 145, 148 (Fig. 2) - can be approximated by two sides of an isosceles triangle. When one changes the length of the sides $(50 \mathrm{~m})$ caused by temperature changes of $1^{\circ} \mathrm{C}$ (extending each of the sides by only $0.0006 \mathrm{~m}$ ), one obtains the change of the position - the apex of the triangle (middle point of the arc) of $0.003 \mathrm{~m}$. As a result of the temperature load one gets the change of the elevation of the midpoint of $0.003 \mathrm{~m} /{ }^{\circ} \mathrm{C}$. It is obvious that in this case, not only the dimensions (length) but also the shape of the item are important. For the set temperature range, for the shape and dimensions of a single element (I section tension member) it would be a virtually linear relationship. Similarly, in the case of the free hanging for a single suspension member (cable) which is of a catenary shape the relationship between the size of a sag (the same elevation) and a temperature change described in [9] is a linear relationship. In the construction of the suspended roof of the open-air theatre in Koszalin the suspension members are not anchored at fixed sites, but they are attached to a deformable steel arch. For the entire grid (Fig. 2), which is formed by 22 suspension members and 20 tension members connected together and with two steel double hinged arches cooperating with six pairs of guys, containing a total of more 400 nodes, such a direct linear relationship cannot be established.

An alternative which takes into account the vertical displacement caused by temperature load by means of numerical calculations (using a computational model of the structure) is its determination based on the current results of surveying. In this work, there are attempts to use the archived data using the basic tools of a statistical analysis, knowing that the results of the work can be used to the limited extend (only for selected points of the structure) and they require further verification, both on the basic of numerical calculations and subsequent measurements. 
For this purpose, to check whether there is a relationship between the temperature recorded under the suspended roof during measurements and the elevation of a grid node in a controlled item determined and to assess the strength of this relationship, Pearson correlation coefficient $(r)$ was used. The collected material allowed to use geometric data (coordinates of controlled points) set at temperatures: $-5^{\circ} \mathrm{C},-3^{\circ} \mathrm{C}, 2^{\circ} \mathrm{C}, 8^{\circ} \mathrm{C}, 12^{\circ} \mathrm{C}, 14^{\circ} \mathrm{C}$ and $34^{\circ} \mathrm{C}$. For each of the controlled points (indicated in Figure 2) correlation coefficients (between the $\mathrm{Z}$ coordinates and temperature $T)$ and their values for the sets of points $\left(r_{\text {avg }}\right)$, a linear regression coefficient and a standard deviation of prediction were calculated (Tab. 1).

It confirmed a strong correlation $(r>0.96)$ between the temperature and the elevation of the selected points, in particular the points located in the central part of the suspended roof. The standard deviation of the prediction in the case of linear regression does not exceed $0.015 \mathrm{~m}$.

Table 1. The correlation and linear regression coefficients

\begin{tabular}{|c|c|c|c|c|}
\hline $\begin{array}{l}\text { Point } \\
\text { number }\end{array}$ & $\begin{array}{l}\text { Correlation } \\
\text { coefficient } r\end{array}$ & $\begin{array}{l}\text { Average correlation } \\
\text { coefficient } r_{\text {avg }}\end{array}$ & $\begin{array}{l}\text { Linear regression } \\
\text { coefficient }\left[\mathrm{m} /{ }^{\circ} \mathrm{C}\right]\end{array}$ & $\begin{array}{c}\text { Standard deviation } \\
\text { of prediction }[\mathrm{m}]\end{array}$ \\
\hline 118 & 0.988 & \multirow{4}{*}{0.988} & 0.0049 & 0.011 \\
\hline 119 & 0.987 & & 0.0048 & 0.012 \\
\hline 141 & 0.987 & & 0.0048 & 0.011 \\
\hline 140 & 0.988 & & 0.0049 & 0.011 \\
\hline 58 & 0.987 & \multirow{4}{*}{0.983} & 0.0043 & 0.009 \\
\hline 59 & 0.980 & & 0.0042 & 0.012 \\
\hline 43 & 0.982 & & 0.0039 & 0.010 \\
\hline 44 & 0.984 & & 0.0038 & 0.010 \\
\hline 221 & 0.986 & \multirow{4}{*}{0.982} & 0.0049 & 0.010 \\
\hline 220 & 0.989 & & 0.0046 & 0.009 \\
\hline 235 & 0.969 & & 0.0049 & 0.015 \\
\hline 236 & 0.983 & & 0.0049 & 0.011 \\
\hline 316 & 0.973 & \multirow{2}{*}{0.968} & 0.0006 & 0.002 \\
\hline 311 & 0.962 & & 0.0007 & 0.002 \\
\hline 381 & 0.973 & \multirow{2}{*}{0.979} & 0.0006 & 0.002 \\
\hline 376 & 0.984 & & 0.0006 & 0.001 \\
\hline 123 & 0.983 & \multirow{2}{*}{0.988} & 0.0032 & 0.007 \\
\hline 136 & 0.992 & & 0.0029 & 0.005 \\
\hline 114 & 0.979 & \multirow{2}{*}{0.970} & 0.0030 & 0.007 \\
\hline 145 & 0.962 & & 0.0033 & 0.011 \\
\hline
\end{tabular}


For further detailed analysis four points in the central part: 118, 119, 141, 140 (Fig. 2), for which in the expert opinion [8] the limit value of the vertical displacement was pointed out, were selected. For the set of input data, in addition to the linear regression the quadratic polynomial and the exponential function could be also used. The results were juxtapositioned in Table 2.

Table 2. Different types of trend lines and their characteristics

\begin{tabular}{||c|c|c|c||}
\hline \multirow{2}{*}{$\begin{array}{c}\text { Point } \\
\text { number }\end{array}$} & \multicolumn{2}{|c|}{ Types of trend lines, the regression equation and determination coefficient $R^{2}$} \\
\cline { 2 - 4 } & linear $Z[\mathrm{~m}]$ & quadratic polynomial $Z[\mathrm{~m}]$ & exponential $Z[\mathrm{~m}]$ \\
\hline \hline \multirow{2}{*}{118} & $Z=0.0049 T+19.214$ & $Z=-1.83 E-05 T^{2}+0.0055 T+19.214$ & $Z=19.214 e^{0.0003 T}$ \\
& $R^{2}=0.9758$ & $R^{2}=0.9781$ & $R^{2}=0.9756$ \\
\hline \multirow{2}{*}{119} & $Z=0.0048 T+19.212$ & $Z=-1.54 E-05 T^{2}+0.0052 T+19.212$ & $Z=19.212 e^{0.0002 T}$ \\
& $R^{2}=0.9732$ & $R^{2}=0.9749$ & $R^{2}=0.9730$ \\
\hline \multirow{2}{*}{141} & $Z=0.0048 T+19.226$ & $Z=-1.52 E-05 T^{2}+0.0052 T+19.226$ & $Z=19.226 e^{0.0002 T}$ \\
& $R^{2}=0.9741$ & $R^{2}=0.9758$ & $R^{2}=0.9740$ \\
\hline \multirow{2}{*}{140} & $Z=0.0049 T+19.224$ & $Z=-2.27 E-05 T^{2}+0.0056 T+19.223$ & $Z=19.224 e^{0.0003 T}$ \\
& $R^{2}=0.9759$ & $R^{2}=0.9794$ & $R^{2}=0.9756$ \\
\hline
\end{tabular}

The standard deviation of the prediction while using the quadratic regression and the exponential for the elevation of each point $(118,119,141,140)$ does not differ from the values obtained for the linear regression (is $0.012 \mathrm{~m}$ ).

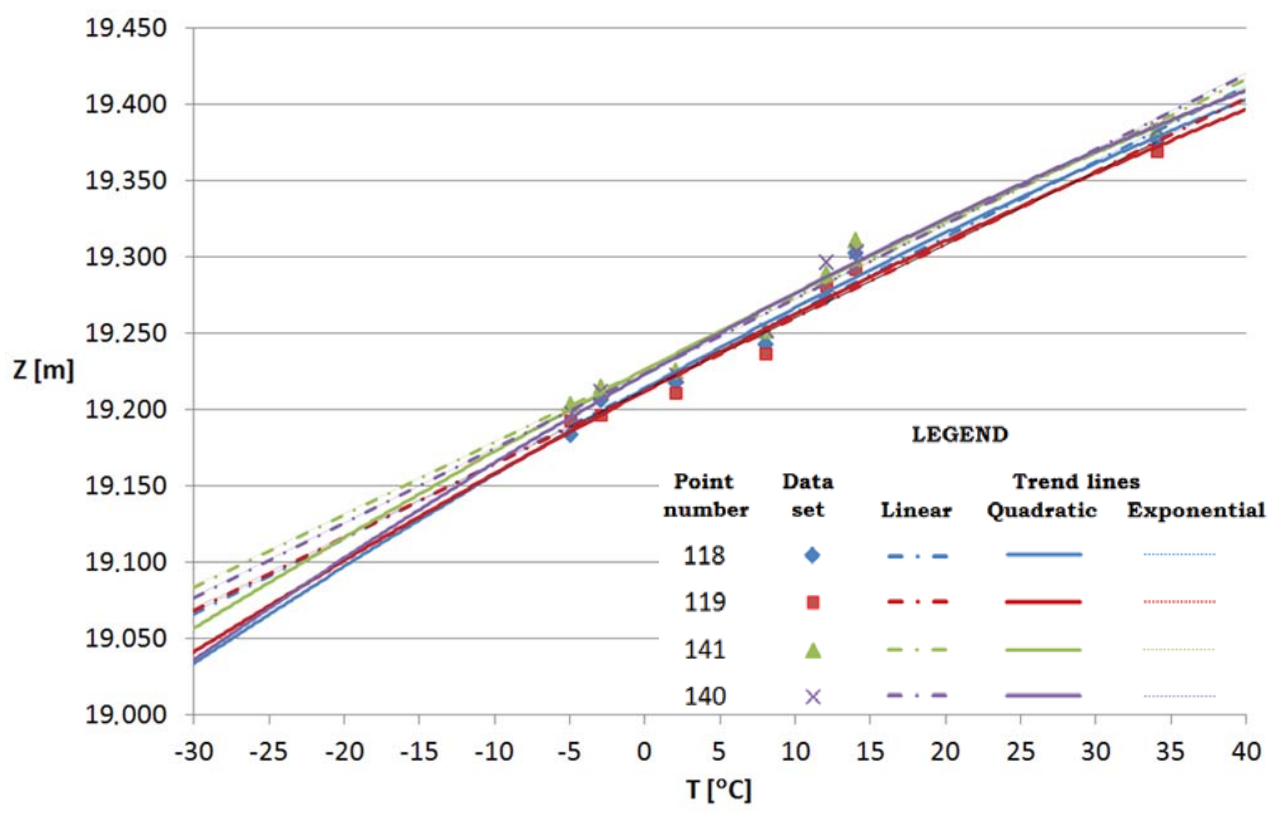

Fig. 3. Approximated trend lines 
The values of the determination coefficient $R^{2}$ in each case are bigger than 0.97 . While predicting the values of the temperature $T$ with the use of various types of trend lines, there occurred noticeable differences in the linear (and exponential) and quadratic regression for temperatures below $-10^{\circ} \mathrm{C}$ (Fig. 3). The differences within the values determined on the basis of the trend line using linear and exponential regression of the temperature range from $-30^{\circ} \mathrm{C}$ to $40^{\circ} \mathrm{C}$ are practically neglected. Elevation values estimated with the use of the trend lines for the calculating temperatures $T_{\min }=T_{\text {out }}$ (Tab. 3), $T_{\max }$ (Tab. 4) i $T_{0}$ (Tab. 5) of the object were compared. The differences between the obtained solutions and in case of $T_{0}$ the residual values were also calculated.

Table 3. Elevations and their differences for $T_{\min }=T_{\text {out }}=-27^{\circ} \mathrm{C}$

\begin{tabular}{|c|c|c|c||}
\hline \multirow{2}{*}{\begin{tabular}{c}
\multirow{2}{*}{$\begin{array}{c}\text { Point } \\
\text { number }\end{array}$} \\
\cline { 2 - 3 }
\end{tabular}} & \multicolumn{2}{|c|}{ Z predicted [m] } & \multirow{2}{*}{$\begin{array}{c}\text { Differences of } \\
\text { predicted values [m] }\end{array}$} \\
\hline \hline 118 & 19.082 & 19.052 & 0.030 \\
\hline 119 & 19.082 & 19.060 & 0.022 \\
\hline 141 & 19.096 & 19.075 & 0.021 \\
\hline 140 & 19.092 & 19.055 & 0.037 \\
\hline
\end{tabular}

Table 4. Elevations and their differences for $T_{\max }=38^{\circ} \mathrm{C}$

\begin{tabular}{||c|c|c|c|}
\hline \multirow{2}{*}{$\begin{array}{c}\text { Point } \\
\text { number }\end{array}$} & \multicolumn{2}{|c|}{ Z predicted [m] } & \multirow{2}{*}{$\begin{array}{c}\text { Differences of } \\
\text { predicted values [m] }\end{array}$} \\
\cline { 2 - 3 } & linear & quadratic & 0.004 \\
\hline \hline 118 & 19.400 & 19.397 & 0.007 \\
\hline 119 & 19.394 & 19.387 & 0.006 \\
\hline 141 & 19.408 & 19.402 & 0.007 \\
\hline 140 & 19.410 & 19.403 & .007 \\
\hline
\end{tabular}

Table 5. Elevations and their differences for $T_{0}=8^{\circ} \mathrm{C}$ and $T=8^{\circ} \mathrm{C}$

\begin{tabular}{||c|c|c|c|c|c|c||}
\hline \multirow{2}{*}{$\begin{array}{c}\text { Point } \\
\text { number }\end{array}$} & \multicolumn{2}{|c|}{$\begin{array}{c}T_{0}=8^{\circ} \mathrm{C} \\
Z \text { predicted }[\mathrm{m}]\end{array}$} & $\begin{array}{c}\text { Differences } \\
\text { of predicted } \\
\text { values } \\
{[\mathrm{m}]}\end{array}$ & \multicolumn{2}{|c|}{$\begin{array}{c}T=8^{\circ} \mathrm{C} \\
Z \text { of the } \\
\text { measurement } \\
{[\mathrm{m}]}\end{array}$} & \multicolumn{2}{c|}{$\begin{array}{c}\text { Differences between } \\
Z \text { predicted and } Z \text { of the } \\
\text { measurement } T_{0}-T[\mathrm{~m}]\end{array}$} \\
\cline { 2 - 5 } & linear & quadratic & linear & quadratic \\
\hline \hline 118 & 19.253 & 19.257 & 0.004 & 19.244 & 0.009 & 0.013 \\
\hline 119 & 19.250 & 19.253 & 0.003 & 19.238 & 0.012 & 0.015 \\
\hline 141 & 19.264 & 19.267 & 0.003 & 19.253 & 0.011 & 0.014 \\
\hline 140 & 19.263 & 19.266 & 0.004 & 19.253 & 0.010 & 0.013 \\
\hline
\end{tabular}


For the air temperature which equals the initial temperature $T_{0}=8^{\circ} \mathrm{C}$ differences between predicted values determined using both regression models (trend lines) do not exceed $0.004 \mathrm{~m}$ (Tab. 5). When using a linear regression residual values for $T=8^{\circ} \mathrm{C}$ (differences in the predicted and measured elevations) do not exceed the value of the standard deviation of the prediction, while for the quadratic polynomial regression only slightly exceed it.

\section{Summary and Conclusions}

Tension structures are characterized by physical and geometrical non-linearity. There is no proportionality between a load and a displacement. Changing of the snow and ice load and the temperature does not cause a linear increase of vertical displacements of selected nodes. On the basis of the conducted analysis and their results (only for the temperature load) it must be concluded that for selected single points of a tested structure the relationship will be similar to the linear relationship.

Characteristic temperatures accepted in accordance with the standard [15] define the scope of changes for which they should be expected for the given structure.

Based on the results of the calculations, the location of the selected grid of nodes for a calculating temperature $T_{0}=8^{\circ} \mathrm{C}$ and higher can be predicted. Due to the possible application of a sample in this temperature range, the reliability and accuracy of a prediction is higher than for temperatures below $-10^{\circ} \mathrm{C}$ or $-15^{\circ} \mathrm{C}$. Independenly of the used regression model, predicted changes in the position of selected points $(118,119,141,140)$ (Fig. 2) caused by the additional load temperature (the temperature change $-22^{\circ} \mathrm{C}$, from $-5^{\circ} \mathrm{C}$ to $-27^{\circ} \mathrm{C}$ ) are more than $10 \mathrm{~cm}$. This value is significant because it makes up $15 \%$ of the limit value of the displacement caused only by an additional snow load. The accuracy of the results (the elevation of a selected point, and thus determining the vertical displacements using the method of the coordinate differences) depends mainly on the accuracy of the registration of the position of the controlled points and the accuracy of determining the temperature.

It is necessary to design a calculating model of a structure taking into account the simultaneous snow, ice and temperature loads and as well as its verification and calibration based on the results of surveys. The verification of the correctness of a construction of the calculating model for such complex and difficult for numerical analyses objects is one of objectives for conducting measurements in [1]. Both theoretical considerations and the results of the analyses indicate the need for further research in this area - including the use of thermovision technology. 


\section{References}

[1] Deska K.: Metodyka rejestracji struktury geometrycznej przekryć budowlanych na potrzeby diagnostyczne. WGiGP UWM w Olsztynie, Olsztyn 2010 [Ph.D. thesis].

[2] Deska K., Pawłowski W.: Badania doświadczalne z zakresu sposobu sygnalizacji punktów przekryć wiszacych na potrzeby pomiarów diagnostycznych. Zeszyty Naukowe Politechniki Łódzkiej, Budownictwo, nr 56, 2007, pp. 71-90.

[3] Deska K., Pawłowski W.: Registration of geometrical structure of a large-span suspended roof for diagnostic purposes. Reports on Geodesy, no. 2 (87), 2009, pp. 309-316.

[4] Deska K., Pawłowski W.: Measurements of large-span roofs - diagnostic aspects. Reports on Geodesy, no. 1 (90), 2011, pp. 107-113.

[5] Filipkowski J.: Construction of suspended roof over open-air theatre in Koszalin. Proceedings of Institution of Civil Engineers, part 1, 1977, pp. 463-472.

[6] Filipkowski J., Deska K.: Struktura geometryczna konstrukcji wiszacej i stan przemieszczenia wywołany ciężarem śniegu. XXV Konferencja Naukowo-Techniczna „Awarie budowlane 2011”, Międzyzdroje 2011, pp. 569-576.

[7] Filipkowski J., Deska K.: Badanie konstrukcji dachu obciażonego śniegiem. Builder, nr 1, 2012, pp. 81-85.

[8] Filipkowski J., Jacoszek J., Deska K.: Sposób odśnieżania zadaszenia amfiteatru $w$ Koszalinie, cz. 2. Opracowanie zamawiane przez MOK w Koszalinie, Koszalin 2006.

[9] Gocał J.: Eliminowanie wpływów termicznych w pomiarach strzatki zwisu lin. Zeszyty Naukowe AGH, Geodezja, nr 879, z. 73, 1982, pp. 33-42.

[10] Janusz J.: Metodyka geodezyjnego badania naprężeń i wydłużeń lin w konstrukcjach ciegnowych. Prace Instytutu Geodezji i Kartografii, t. XLIV, z. 94, 1996.

[11] Krentowski J., Tribułło R.: Analiza wpływu obciążenia temperatura na stan odkształceń i zagrożeń konstrukcji budowlanych. Budownictwo i Inżynieria Środowiska, nr 2, 2011, pp. 155-162.

[12] Łapko A.: Wyznaczanie obcią̇eń temperatura. Builder, nr 3, 2008, pp. 72-74.

[13] Pałkowski S.: Konstrukcje cięgnowe. WNT, Warszawa 1994.

[14] Pałkowski S.: Wybrane zagadnienia obliczania i projektowania konstrukcji stalowych. Wyd. Politechniki Koszalińskiej, Koszalin 1998.

[15] PN-EN 1991-1-5:2005 Eurokod 1: Oddziaływania na konstrukcje. Część 1-5: Oddziaływania ogólne. Oddziaływania termiczne. Z załąznikiem krajowym (Z) PN-EN 19911-5. PKN, Warszawa 2005.

[16] Wróbel A.: Applications of thermovision in engineering measurements. Reports on Geodesy, no. 1(82), 2007, pp. 409-416.

[17] Żurański J.A., Sobolewski A.: Obciązenie śniegiem w Polsce. Wyd. Instytutu Techniki Budowlanej, Warszawa 2009. 